\section{JURNAL ABDIMAS

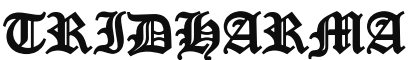

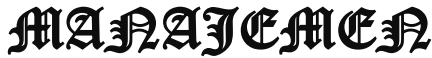

P-ISSN 2615-6849, E-ISSN 2716-070X

Jurnal ABDIMAS Vol. 1,No.2, Mei 2020,Hal(99-109)

@Prodi Manajemen Fakultas Ekonomi Universitas Pamulang

Email: abdimasjurnal.unpam@gmail.com Telp: (021) 741-2566

\title{
PEMANFAATAN WEB E-COMMERCE UNTUK MENINGKATKAN DAYA SAING USAHA KECIL MENENGAH
}

\author{
Khotimatus Sa'diyah, Evita Vibriana, Niera Feblidiyanti \\ Dosen Ekonomi Fakultas Ekonomi Universitas Pamulang
}

Email:diyah.khotimatus@gmail.com,evitavw@gmail.com,nira_coeet@yahoo.com

\begin{abstract}
ABSTRAK
Sosial media sekarang telah memiliki peran penting dalam strategi pemasaran bagi bisnis kecil maupun besar. Kini berbagi informasi kepada pengunjung atau follower bukan satu-satunya keuntungan menggunakan sosial media bagi sebuah bisnis. Jauh lebih yang utama adalah agar produk dapat laku dipasar dan banyak diminati pelanggan. Pengabdian Kepada Masyarakat kali ini berjudul "Pemanfaatan Web E-Commerce Untuk Meningkatkan Daya Saing Usaha Kecil Menengah".

Adapun mitra dalam program kegiatan Pengabdian Kepada Masyarakat kali ini adalah pelaku Usaha Kecil Mikro Pertanian (UKMP) kota Depok yang berada di Desa Sukmajaya, Depok, Jawa Barat. Pelaku usaha mengeluhkan tentang penjualan mereka yang kurang berkembang meskipun sudah menggunakan sosial media dalam pemasarannya sehingga kurang memberikan profit secara maksimal.

Berdasarkan permasalahan yang dihadapi anggota pelaku Usaha Kecil Mikro Pertanian kota Depok, melalui kegiatan pengabdian kepada masyarakat para dosen dan mahasiswa dari Universitas Pamulang,mencoba membantu pelaku usaha melalui pengembangan metode pemasaran melalui web e-commerce secara tepat agar usahanya bisa berkembang. Diharapkan dengan penyuluhan penggunakan web e-commerce sebagai alat bantu pemasaran dapat meningkatkan penjualan produk.

Metode pelaksanaan pengabdian ini dilakukan dalam beberapa kegiatan yaitu tahap persiapan meliputi observasi dan perizinan, penyusunan penganggaran kegiatan, pengajuan proposal, dan tahap implementasi pelaksanaan kegiatan pengabdian kepada masyarakat yakni melalui metode ceramah, diskusi dan tanya jawab.

Kesimpulan dari pengabdian ini adalah pelaksanaan pengabdian kepada masyarakat di Balai Pertemuan Desa Sukmajaya Kelurahan Rangkapan Jaya Kecamatan Pancoran Mas, Kota Depok pada 5 - 6 Oktober 2019 dengan tema pemasaran menggunakan web e-commerce terbukti dapat meningkatkan pengembangan produk mitra bisnis baik dari sisi pendapatan maupun dari sisi pengurangan biaya pemasaran.
\end{abstract}

\section{Kata Kunci: Pemasaran, UKM, Sosial media, e-Commerce}

\begin{abstract}
ABSTRAC
Social media now has an important role in marketing strategies for small and large businesses. Now sharing information with visitors or followers is not the only advantage of using social media for a business. Far more important is that our products sell well and are in great demand by customers. This time the Community Service is entitled The Use of E-Commerce Web to Improve the Competitiveness of Small and Medium Enterprises.

The partners in the Community Service program this time are the Depok Micro Farming Small Business (UKMP) in the village of Sukmajaya, Depok, West Java. Business actors
\end{abstract}




\section{JURNAL ABDIMAS

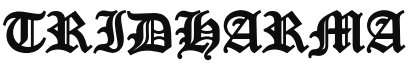

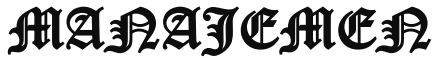

P-ISSN 2615-6849, E-ISSN 2716-070X

Jurnal ABDIMAS Vol. 1,No.2, Mei 2020,Hal(99-109)

@Prodi Manajemen Fakultas Ekonomi Universitas Pamulang

Email: abdimasjurnal.unpam@gmail.com Telp: (021) 741-2566

complained about their underdeveloped sales despite using social media in their marketing, so they did not provide maximum profit.

Based on the problems faced by members of the Depok Agriculture Micro Small Business actors, through community service activities, lecturers and students from Pamulang University try to help businesses through developing marketing methods through e-commerce web appropriately so that their businesses can develop. It is expected that by counseling the use of e-commerce web as a marketing tool can increase product sales.

This method of implementing community service is carried out in a number of activities, including the preparation phase including observation and licensing, preparation of activity budgeting, submission of proposals, and the implementation phase of the implementation of community service activities through lecture, discussion and question and answer methods..

The conclusion of this service is the implementation of community service at the Sukmajaya Village Meeting Center, Rangkap Jaya Village, Pancoran Mas District, Depok City on 5-6 October 2019 with the theme of marketing using web e-commerce proven to be able to increase the development of business partner products both in terms of revenue and from the reduction in marketing costs.

\section{Keywords: Marketing, Small and Medium Enterprises, Social media, e-Commerce}

\section{PENDAHULUAN}

Konsep pemasaran mengatakan bahwa kunci untuk mencapai tujuan organisasi terdiri dari penentuan kebutuhan dan keinginan pasar sasaran serta memberikan kepuasaan yang diharapkan secara lebih efektif dan efisien dibandingkan para pesaing.Perkembangan tehnologi saat berkembang sangat pesat, sehingga mau tidak mau masyarakat harus mengikuti perkembangan tehnologi tersebut, bila tidak mengikuti akan ketinggalan. Penggunaan social media adalah alat pemasaran yang paling ampuh karena semua orang dari berbagai latar belakang yang berbeda, sangat aktif menggunakannya. Dengan social media pelaku usaha dapat menjalin interaksi secara luas dengan berbagai kalangan, dengan yang murah dan sesuai untuk memasarkan produk mereka, sehingga apa yang ditawarkan memiliki peluang besar untuk terjual.Salah satu Usaha atau bisnis lewat internet (dengan menggunakan elektronik) ini sering diseut dengan electronic commerce (E-Commerce) atau Electronic business (E-Business). ECommerce adalah suatu proses berbisnis dengan memakai teknologi elektronik yang menghubungan antara perusahaan, konsumen dan masyarakat dalam bentuk transaksi elektronik dan pertukaran/ penjualan barang, servis, dan informasi secara elektronik.

Usaha Kecil dan Menengah atau UKM merupakan suatu usaha yang dibentuk dan diselenggarakan oleh masyarakat, kalangan menengah kebawah. Dimana usahanya adalah usaha rumahan. Meskipun usaha kecil dan menengah ini memiliki skala kecil, keberadaan usaha ini di tengah masyarakat memiliki manfaat yang besar baik bagi masyarakat dan juga sebagai salah satu pendorong manfaat pembangunan ekonomi Negara.

Perkembangan usaha kecil dan menengah tentunya sangat berpengaruh pada negara yang masih berkembang seperti negara Indonesia. Hal yang lebih penting adalah menumbuhkan jiwa wirausaha dimasyarakat, sehingga dapat menyerap lapangan pekerjaan dan mengurangi jumlah pengangguran.

Kami selain dosen Prodi Akuntansi Universitas Pamulang juga berperan dalam masyarakat melalui kegiatan Pengabdian Kepada Masyarakat (PKM), melalui penyuluhan mengenai pemasaran produk kepada pelaku usaha kecil dan menengah bertujuan untuk memberikan pemahaman dan sosialisasi kepada pelaku UMKM mengenai strategistrategi pemasaran yang tepat agar dapat mengoptimalkan profit yang diinginkan, 


\section{JURNAL ABDIMAS

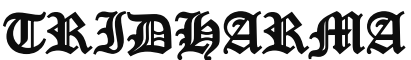

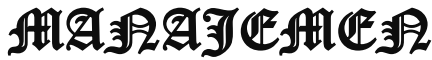

P-ISSN 2615-6849, E-ISSN 2716-070X

Jurnal ABDIMAS Vol. 1,No.2, Mei 2020,Hal(99-109)

@ Prodi Manajemen Fakultas Ekonomi Universitas Pamulang

Email: abdimasjurnal.unpam@gmail.com Telp: (021) 741-2566 sehingga terbentuklah kegiatan pengabdian kepada masyarakat dengan judul "PEMANFAATAN WEB E-COMMERCE UNTUK MENINGKATKAN DAYA SAING USAHA KECIL MENENGAH." Adapun sasaran pengabdian yaitu para anggota UKM pertanian di Desa Sukmajaya - Depok dengan tempat pelaksanaan di Balai Pertemuan Desa Sukmajaya - Depok.

\section{RUMUSAN MASALAH}

Dengan mempertimbangkan latar belakang yang telah diutarakan diatas, rumusab masalah kegiatan pengabdian ini adalah:

1. Memberikan pemahaman dan sosialisasi kepada pelaku UMKM mengenai strategi-strategi pemasaran yang tepat agar dapat mengoptimalkan profit yang diinginkan.

2. Memberikan pemahaman tentang social media kepada pelaku usaha kecil.

3. Memberikan pelatihan tentang pemanfaatan web e-commerce.

\section{TUJUAN PELAKSANAAN}

Tujuan kegiatan pengabdian masyarakat ini adalah untuk mengembangkan dan membangkitkan kembali kegiatan pemasaran online secara intensif. Kanalisasi pemasaran online juga di tambah, tidak hanya pada whatsapp, ataupun social media lainnya, seperti facebook dan instagram, tetapi juga optimalisasi layanan e-commerce. Secara rinci, tujuan kegiatan ini diantaranya untuk :

1.Memahami strategi - strategi pemasaran yang tepat agar dapat mengoptimalkan profit yang diinginkan.

2.Menumbuhkan jiwa usaha kreatif melalui pemanfatan social media

3.Mempraktikan pemanfaatan web ecommerce guna meningkatkan pelaku usaha kecil menengah.

\section{TINJAUAN PUSTAKA}

\section{Pengertian UKM}

Usaha Kecil dan Menengah atau UKM merupakan suatu usaha yang dibentuk dan diselenggarakan oleh masyarakat, yang bukan berasal dari kalangan atas atau orang kaya. Pada umumnya, terbentuknya usaha ini berasal dari ide satu orang atau beberapa orang dalam suatu organisasi masyarakat. Meskipun usaha kecil dan menengah ini memiliki skala kecil, keberadaan usaha ini di tengah masyarakat memiliki manfaat yang besar baik bagi masyarakat dan juga sebagai salah satu pendorong manfaat pembangunan ekonomi Negara.

Perkembangan usaha kecil dan menengah sangat memiliki pengaruh yang besar pada negara, terutama pada negara yang masih berkembang. Dalam suatu negara manfaat usaha kecil dan menengah berperan dalam mengembangkan masyarakat mandiri dan meningkatkan pertumbuhan ekonomi. Dalam usaha ini masyarakat berperan langsung sebagai penggagas, pelaksana dan pengendali. Aspek lain yang juga bermanfaat bagi masyarakat sekitarnya adalah adanya manfaat jiwa wirausaha, karena jiwa wirausaha yang dimiliki masyarakat dapat membantu berkembangnya masyarakat mandiri dan secara tidak langsung dapat mengurangi jumlah pengangguran.

Di bawah ini adalah beberapa manfaat atau fungsi dari usaha kecil dan menengah bagi suatu negara:

a. Terbukanya lapangan pekerjaan

Salah satu manfaat usaha bagi masyarakat dengan usaha kecil dan menengah ini dapat membuka kesempatan kerja yang lebih luas pada masyarakat. Dengan adanya usaha ini, dapat mengurangi jumlah pengangguran di tengah masyarakat. Apalagi usaha ini tidak memerlukan spesifikasi pendidikan yang tinggi. Sehingga masyarakat dengan pendidikan rendah bahkan tidak mengenyam pendidikan pun dapat melakukan usaha, asal memiliki keterampilan atau sudah terlatih. 


\section{JURNAL ABDIMAS

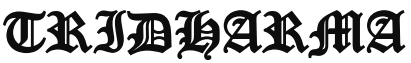

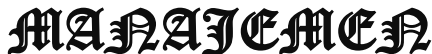

P-ISSN 2615-6849, E-ISSN 2716-070X

Jurnal ABDIMAS Vol. 1,No.2, Mei 2020,Hal(99-109)

@Prodi Manajemen Fakultas Ekonomi Universitas Pamulang

Email: abdimasjurnal.unpam@ gmail.com Telp: (021) 741-2566 b. Dapat meningkatkan angka produk domestik bruto

Produk domestik bruto merupakan sebuah nilai makro ekonomi suatu negara dilihat dari kemampuan negara tersebut dalam melakukan produksi suatu jasa atau barang dalam jangka waktu tertentu. Hal ini akan menunjukkan seberapa besar kemampuan ekonomi pada suatu negara. Usaha kecil dan menengah adalah salah satu penyumbang pajak negara yang cukup besar, karena keberadaannya yang banyak di tengah masyarakat. Sehingga manfaat bisnis sendiri atau mandiri masyarakat ini secara tidak langsung membentuk dalam peningkatanpertumbuhan, pembangunan dan kemajuan negara.

c. Meningkatkan ekonomi Negara Usaha kecil dan menengah di tengah masyarakat keberadaannya semakin marak, karena mudah untuk dimulai dan pelaksanaannya yang fleksibel. Manfaat usaha kecil dan menengah secara langsung adalah mengangkat perekonomian masyarakat menengah ke bawah. Usaha ini memiliki manfaat yang lebih besar yaitu secara tidak langsung dapat mendukung pertumbuhan ekonomi negara. Dengan adanya usaha kecil dan menengah dapat meningkatkan pendapatan nasional yang diperoleh negara.

d. Solusi usaha untuk masyarakat kecil Manfaat membuka usaha kecil dan menengah ini adalah sebagai salah satu solusi perekonomian masyarakat menengah ke bawah, yang memiliki latar belakang pendidikan kurang walaupun faktanya ada pelaku usaha ini yang memiliki pendidikan tinggi. Masyarakat dapat memulai usaha ini sesuai dengan kemampuannya tanpa ada persyaratan khusus. Untuk memajukan usaha ini, pemerintah juga telah memberikan fasilitas seperti pelatihan, modal atau dalam pengembangan usaha.
Dari beberapa manfaat usaha kecil dan menengah di atas dapat disimpulkan bahwa keberadaan usaha ini di tengah masyarakat tidak hanya sebatas pengembangan perekonomian masyarakat saja. Namun juga meliputi banyak aspek yang juga bermanfaat bagi masyarakat sekitarnya dan dalam membantu pertumbuhan pembangunan ekonomi negara. Manfaat jiwa wirausaha di sini sangatlah penting, karena jiwa wirausaha yang dimiliki masyarakat dapat membantu berkembangnya masyarakat mandiri dan secara tidak langsung dapat mengurangi jumlah pengangguran.

Pemasaran merupakan elemen penting dalam menjalankan sebuah bisnis. Banyak pelaku bisnis yang meluangkan waktunya untuk memikirkan metode/ cara/ strategi pemasaran apa yang tepat agar barang yang dijualnya laku di pasaran dan omsetnya cepat meningkat. Hal ini berpengaruh terhadap sukses tidaknya bisnis karena bergantung pada metode/ cara pemasarannya.berikut beberapa hal penting yang kalau diterapkan setidaknya bisa mendatangkan konsumen, diantaranya:

1. Spesifikasi Produk

Spesifikasi produk merupakan poin penting sebelum menjual barang. Spesifikasi berisi informasi detail mengenai aspek dan bahan dalam pembuatan produk. Spesifikasi produk wajib disertakan pada kolom informasi produk. Tujuannya agar calon pembeli bisa membayangkan seperti apa produk yang akan dibelinya. Pembeli juga dapat mempertimbangkan antara harga dan kualitas produk. Apabila produk berkualitas, pembeli pasti tidak berkeberatan mengeluarkan uang yang banyak demi produk tersebut.Adanya spesifikasi juga sebagai perbandingan antara produk yang Anda jual dan produk dari brand lain. Dengan demikian, pembeli juga bisa mengetahui kelebihan dan kelemahan dari setiap produk.

2. Segmentasi Pasar 


\section{JURNAL ABDIMAS

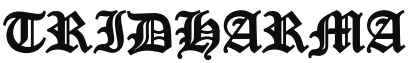

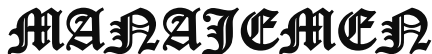

P-ISSN 2615-6849, E-ISSN 2716-070X

Jurnal ABDIMAS Vol. 1,No.2, Mei 2020,Hal(99-109)

@Prodi Manajemen Fakultas Ekonomi Universitas Pamulang

Email: abdimasjurnal.unpam@gmail.com Telp: (021) 741-2566
Keadaan ekonomi sangat berpengaruh terhadap daya beli masyarakat. Konsumen yang berpenghasilan tinggi cenderung bersikap konsumtif dan tidak terlalu memedulikan harga barang. Asalkan barang tersebut berkualitas dan unik, harga bukanlah masalah.Berbeda dengan konsumen yang berpenghasilan rendah, harga menjadi patokan saat memutuskan apakah melakukan pembelian atau tidak.Selain keadaan ekonomi, faktor selera dan kebutuhan juga menjadi poin yang membedakan konsumen satu dan konsumen lainnya.

Adanya segmentasi pasar akan membantu untuk menargetkan kepada siapa produk tersebut harus dijual dan bagaimana cara agar informasi mengenai produk tersebut sampai ke konsumen.

3. Menentukan Target Pemasaran

Target pemasaran berkaitan dengan kepada siapa produk tersebut akan dijual. Sebelum menjual produk, ada baiknya jika pelaku bisnis mengamati budaya masyarakat saat membeli barang.Pada poin ini, pelaku bisnis harus melakukan pengamatan langsung di lapangan. Lakukan wawancara singkat dengan para konsumen.Setelah Anda mendapatkan informasi mengenai target pemasaran secara lengkap, maka pelaku usaha dapat segera membuat produknya.

Susunlah strategi apa yang harus ditetapkan agar produk tersebut laku dijual di pasaran. Lakukan promosi secara bertubi-tubi dengan menempelkan brosur atau iklan di media sosial.Keberhasilan bisnis juga diukur dari loyalitas konsumen untuk berbelanja di tempat Anda. Karena itu, pikirkanlah bagaimana cara untuk mencuri perhatian konsumen dan menjaga loyalitas mereka terhadap bisnis.

4. Tempat Pemasaran

Setelah mengetahui siapa yang menjadi sasaran penjualan, kini

\begin{abstract}
saatnya menentukan tempat pemasaran. Tempat pemasaran haruslah sesuai dengan target pemasaran.Jika targetnya pasarnya anak muda dan kalangan produktif, alangkah baiknya dipasarkan di area sekitar kampus atau secara online.
\end{abstract}

5. Promosi

Keempat poin di atas tentu akan sukses jika disertai dengan promosi yang tepat. Ada banyak media yang dapat difungsikan sebagai wadah untuk promosi. Misalnya, koran, majalah, televisi, radio, dan sosial media.

Media promosi melalui media elektronik dianggap sangat ampuh untuk menarik perhatian konsumen. Terutama saat ini, masyarakat lebih banyak menghabiskan waktunya di depan gadget untuk mengakses informasi dibandingkan mengamati langsung.Adanya promosi juga membuat bisnis Anda terlihat lebih kompetitif. Usahakan untuk melakukan promosi yang menarik agar konsumen juga tertarik untuk melirik produk yang dijual.

Memasarkan produk kepada konsumen tidaklah mudah. Adanya pesaing membuat pelaku usaha harus benar-benar memikirkan pemasaran seperti apa yang harus dilakukan untuk menggaet konsumen. Sosial media sekarang telah memiliki peran penting dalam strategi pemasaran bagi bisnis kecil maupun besar.Kini berbagi informasi kepada pengunjung atau follower bukan satusatunya keuntungan menggunakan sosial media bagi sebuah bisnis.Banyak UKM di seluruh dunia telah menemukan cara bagaimana sosial media dapat memberikan kontribusi kesuksesan dan perkembangan pada segala aspek.Bertambahnya jenis sosial media yang semakin bervariasi, mulai dari sosial media personal, blog, bahkan eCommerce juga turut mendukung berkembangnya perjalanan bisnis tersebut.

Berikut adalah 10 keuntungan sosial media bagi bisnis: 


\section{JURNAL ABDIMAS

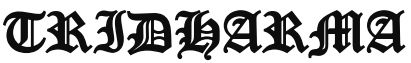

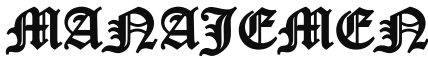

P-ISSN 2615-6849, E-ISSN 2716-070X

Jurnal ABDIMAS Vol. 1,No.2, Mei 2020,Hal(99-109)

@Prodi Manajemen Fakultas Ekonomi Universitas Pamulang

Email: abdimasjurnal.unpam@ gmail.com Telp: (021) 741-2566
1. Cara mudah untuk mencari tahu pelanggan

Salah satu kunci sukses bagi seluruh bisnis dengan mengenal pelanggannya lebih dekat. Sosial media membuat proses pengenalan ini menjadi lebih mudah dibandingkan dengan sebelumnya.Dengan perangkat pendukung yang ada, kini bisa mengetahui dengan terperinci mengenai siapa saja konsumen kita, bahasa yang mereka gunakan, rentang usia, bahkan jenis kelamin dari sosial media.Informasi ini dapat membantu proses branding dan promosi kepada target konsumen yang tepat.Manfaatkan juga trend usia pengguna pada masing-masing sosial media, sebagai acuan Anda dalam memilih chanel promosi.Dengan target konsumen yang tepat diharapkan memberikan keuntungan lebih dari investasi yang telah Anda lakukan.

2. Membantu mencarian target konsumen lebih efektif

Geo-targetting merupakan langkah yang efektif bila Anda ingin mengirimkan pesan kepada target konsumen secara spesifik berdasarkan lokasi mereka.Sosial media seperti Facebook dan Twitter memiliki perangkat pendukung yang membantu Anda untuk menyajikan informasi yang sesuai bagi konsumen.

Contohnya jika anda memiliki bisnis kuliner dan ingin melakukan promosi melalui instagram, postingan foto Anda bisa dilengkapi dengan fitur location atau \#hashtag.

Dengan memanfaatkan fitur location Instagram untuk memasarkan bisnis membuat audiens yang ingin mengunjungi lokasi wisata tersebut bisa tertarik dan memiliki kemungkinan untuk menjadi konsumen dengan demikian konsumen lebih tertarget.

3. Membantu Menemukan Konsumen Baru dan Memperluas Target Pasar
Sosial media seperti Instagram membantu bisnis kecil untuk menemukan konsumen dan mencari konsumen yang potensial.Jika ingin mencari konsumen dengan lokasi yang berdekatan dengan Anda, pencarian berdasarkan lokasi terdekat bisa dilakukan dengan Instagram.Selanjutnya pelaku usaha akan menemukan calon konsumen yang bisa dihubungi sehubungan dengan promosi bisnis yang dilakukan. Lalu untuk mencari konsumen, seperti sebelumnya bisa memanfaatkan \#hashtags yang terkait dengan bisnis anda, kemudian gunakan untuk menemukan calon konsumen yang sesuai.follow/like/comment postingan mereka agar mereka bisa tahu mengenai produk/brand.Dimana pun berada, baik dalam maupun luar negeri, selama dan calon konsumen memanfaatkan sosial media yang sama, maka kedua pihak dapat tetap bertemu dan melakukan transaksi.

4. Memudahkan dalam Memberikan Feedback Secara Langsung

Sosial media untuk bisnis memberikan Anda akses kepada feedback positif maupun negatif dari konsumen, yang merupakan informasi berharga dari sudut pandang konsumen.Sebagai contoh, jika pelaku usaha meluncurkan produk baru dan di bagikan melalui sosial media, maka secara instan bisa langsung mengetahui pendapat konsumen.Cara lain untuk mengetahui perspektif konsumen adalah dengan mempelajari bagaimana cara mereka menggunakan produk. Dengan adanya Fanpage pada Facebook misalnya, konsumen bisa langsung memberikan saran/kritik/pertanyaan pada kolom komentar atau mengirim pesan mengenai produk/layanan.Dengan begini respon konsumen terhadap aspek apapun pada bisnis bisa terlihat dengan jelas. Hasilnya bisa digunakan untuk melakukan improvisasi terhadap kualitas bisnis. 


\section{JURNAL ABDIMAS

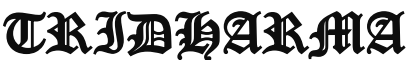

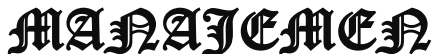

P-ISSN 2615-6849, E-ISSN 2716-070X

Jurnal ABDIMAS Vol. 1,No.2, Mei 2020,Hal(99-109)

@Prodi Manajemen Fakultas Ekonomi Universitas Pamulang

Email: abdimasjurnal.unpam@ gmail.com Telp: (021) 741-2566
5. Mengembangkan Target Pasar dan Selangkah Lebih Maju dari Kompetitor

Dengan sosial media pelaku usaha bisa mendapatkan informasi penting dari kompetitor, yang kemudian dapat meningkatkan strategi pemasaran.Dengan cara ini, bisa menganalisa teknik apa saja yang digunakan oleh kompetitor dan melakukan hal yang lebih baik dari yang mereka lakukan.

Selain itu juga bisa menggunakan sosial media untuk teknik pemasaran yang sedikit nakal, yaitu untuk melihat kelebihan \& kekurangan kompetitor.

Caranya, cari kompetitor atau pendahulu di industri bisnis Anda, lalu perhatikan teknik apa saja yang mereka gunakan. Pelaku usaha bisa melihat siapa saja follower kompetitornya, perhatikan apa yang mereka posting dan apa yang mereka sukai. Dengan demikian pelaku usaha bisa memulai untuk mengembangkan konten yang relevan dengan target audiens dan mendapatkan klien dengan media sosial.

6. Membantu Meningkatkan Pengunjung Website dan Ranking Search Engine

Salah satu keuntungan terbesar dari sosial media bagi bisnis adalah meningkatkan jumlah pengunjung website. Namun tidak hanya kunjungan yang bisa Anda dapatkan. Apabila informasi yang mereka temukan pada website Anda bermanfaat, mereka akan melakukan 'share' di sosial media.Meskipun tidak signifikan tetapi media sosial juga bisa meningkatkan ranking website dengan memberikan sinyal positif kepada search engine.

7. Bagikan Informasi Lebih Cepat dengan Sosial Media

Sebelumnya proses pemasaran mengalami kendala untuk menyajikan informasi kepada konsumen dalam waktu yang singkat.Kini dengan adanya sosial media, penyampaian informasi kepada konsumen menjadi lebih mudah dan cepat.

Saat Anda menggunakan sosial media untuk bisnis, khususnya untuk membagikan informasi mengenai bisnis Anda, cukup klik tombol 'share' pada setiap sosial media yang digunakan. Pastikan bahwa informasi yang dibagikan sesuai dengan minat target konsumen.

Search engine membutuhkan waktu berjam-jam bahkan hari atau minggu agar konten yang baru diposting bisa muncul di halaman pencarian. Tidak seperti sosial media yang bisa menampilkan dengan real time. Apapun yang diposting di sosial media maka akan langsung muncul di timeline follower, sehingga bisa langsung menghasilkan traffic ke website bahkan penjualan. Hal ini tentunya akan efektif jika akun sosial media Anda memiliki follower yang cukup banyak. Kalaupun tidak, mungkin bisa mempertimbangkan menggunakan jasa influencer.

8. Membantu Konsumen Menjangkau Bisnis

Sosial media mampu menjangkau siapapun yang menggunakannya, terlepas apakah itu calon konsumen ataupun bisnis lain yang juga membutuhkan jasa atau produk bisnis Anda.Mereka dapat memanfaatkan sosial media dalam melakukan pencarian produk atau jasa yang mereka butuhkan.

Kini pengguna smartphone semakin meningkat bersamaan juga dengan akses ke sosial media, alasannya sederhana yakni karena lebih praktis.

Begitu pula dengan pencarian produk atau brand, kini konsumen selalu berusaha mencari informasi sebuah brand di sosial media.Hal ini biasanya dilakukan sebelum memutuskan untuk membeli atau menggunakan suatu produk. 


\section{JURNAL ABDIMAS

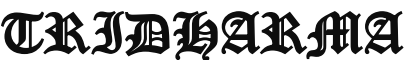

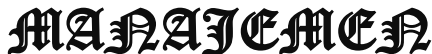

Konsumen melakukan hal ini untuk mencari tahu reputasi brand Anda di sosial media, seperti berapa banyak follower, seperti apa komentar konsumen lain, informasi produk terbaru dan hal lainnya.Selain untuk melihat reputasi, konsumen juga menggunakan sosial media untuk mengukur seberapa terpercayanya brand Anda. Oleh karena itu sosial media penting, karena berada di salah satu tahap yang mendukung keputusan pembelian konsumen.

9. Lebih Dekat dengan Konsumen Melalui Sosial Media

Sosial media merupakan sarana yang sesuai untuk menciptakan hubungan dengan konsumen Anda. Hubungan dengan konsumen dibangun sebelum, pada saat, dan setelah konsumen menggunakan jasa mereka. 'Sebelum' adalah pada saat calon wisatawan melakukan riset mengenai lokasi wisata/jasa di sosial media. 'Pada saat' adalah ketika wisatawan berada di lokasi wisata dan 'setelah' adalah ketika wisatawan selesai berwisata dan memosting konten mereka pada saat liburan.

Komunikasi semacam ini sangat memungkinkan dilakukan melalui sosial media saat ini dibandingkan hanya melalui pemasaran konvensional.

10.Meningkatkan Brand Awareness dan Promosi dengan Biaya yang Minim

Terakhir, sosial media membantu bisnis Anda untuk meningkatkan brand awareness dengan biaya yang bisa dibilang hampir tidak ada. Biaya yang sangat diperlukan untuk hal ini adalah waktu. Pasalnya membangun brand dengan sosial media setidaknya membutuhkan tenaga, proses dan waktu yang tidak singkat.Meskipun tanpa biaya, yang dimaksud disini adalah ketika Anda benar-benar melakukan promosi di sosial media tanpa menggunakan iklan.Hal ini sangat mungkin dilakukan dan hasilnya bisa jauh lebih baik daripada mengandalkan iklan.Harus diingat, pelaku usaha membutuhkan konten yang menarik dan berkualitas. Artinya jika memposting foto, berarti membutuhkan foto dengan kualitas baik untuk bisa menarik perhatian calon konsumen.

\section{METODE PELAKSANAAN}

Sebelum acara Pengabdian Masyarakat dilakukan tim dosen melakukan beberapa agenda antara lain dapat digambarkan dalam alur berikut:

1. Tahap Persiapan

a. Kegiatan Observasi dan Perizinan Observasi dilakukan dengan melakukan survey pada lokasi yang akan dijadikan kegiatan Pengabdian Kepada Masyarakat (PKM) yakni Kelurahan Rangkapan Jaya, Kecamatan Pancoran Mas, Kota Depok, propinsi Jawa Barat. Survey dilakukan 3 kali untk menentukan titik yang tepat yang akan dijadikan sebagai point kegiatan. Dalam tahapan perizinan para dosen berkordinasi dengan pihak terkait, seperti: Lurah Rangkapan Jaya, Ketua RW Rangkapan Jaya dan Ketua RT 03 Rangkapan Jaya dimana kegiatan PKM akan dilaksanakan.

b. Penyusunan RAB

Rencana Anggaran dan Belanja dipersiapkan dalam hal pembelian belanja bahan seperti: Honor narasumber, cinderamata/ plakat, konsumsi, sertifikat, materi, pembuatan jurnal dan door prize serta beberapa peralatan lain nya yaitu: tempat pelatihan, sound system, laptop dan LCD proyektor.

c. Pengajuan Proposal

Proposak kegiatan PKM diajukan pada tanggal 22 September 2019 dan setelah melalui proses review, disetujui oleh Ketua LPPM Bapak 


\section{JURNAL ABDIMAS

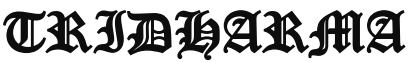

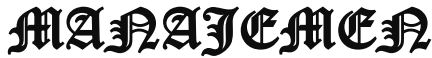

P-ISSN 2615-6849, E-ISSN 2716-070X

Jurnal ABDIMAS Vol. 1,No.2, Mei 2020,Hal(99-109)

@ Prodi Manajemen Fakultas Ekonomi Universitas Pamulang

Email: abdimasjurnal.unpam@gmail.com Telp: (021) 741-2566
Ali Madinsyah pada tanggal 9 Oktober 2019.

2. Tahap Implementasi/ pelaksanaan kegiatan

Kegiatan Pengabdian Kepada Masyarakat (PKM) dilaksanakan di Balai Pertemuan Desa Sukmajaya Kelurahan Rangkapan Jaya Kecamatan Pancoran Mas, Kota Depok pada hari Jum'at, Sabtu dan Minggu tanggal 5 6 Oktober 2019. Dalam pelaksanaan kegiatan ini metode yang digunakan adalah dengan metode ceramah, diskusi dan Tanya jawab. Pada sesi ceramah membahas mengenai pentingnya berwirausaha. Pada sesi diskusi, pelaku usaha diberikan pemahaman tentang aplikasi yang dibutuhkan dalam pemasaran produk secara digital dan pelatihan dalam menggunakan perangkat maupun aplikasi sosial media, sehingga dari aplikasi digital pelaku usahan dapat membuat atau menggunakan salah satu atau beberapa situs penjualan online secara minim biaya. Pada sesi tanya jawab, membahas permasalahan omset pelaku usaha yang belum stabil, yang berdampak pada minimnya modal untuk menggaji tenaga pemasaran/ salesman, omset yang jauh dibawah harapan, adanya kompetitor yang juga menjual produk yang sama, serta penolakan pasar karena pasar sudah membeli produk yang sama pada layanan e-commerce lain.

\section{HASIL DAN PEMBAHASAN}

Pengabdian masyarakat yang dilakukan oleh dosen-dosen program studi Akuntansi telah berjalan dengan lancar dan mendapat sambutan hangat dari tempat pelaksanaan kegiatan ini yaitu para anggota usaha kecil menengah pertanian (UKMP) kota Depok .

\begin{tabular}{llr}
\multicolumn{1}{c}{ Hasil } & yang telah dicapai \\
berdasarkan & pelaksanaan & $\begin{array}{r}\text { kegiatan } \\
\text { Pengabdian }\end{array}$ \\
Kepada Masyarakat & (PKM)
\end{tabular}

yang telah dilaksanakan dapat identifikasi sebagai berikut:

1. Mitra bisnis melakukan pemasaran menggunakan aplikasi penjualan online pada Smartphone yang dimilikinya,mitra bisnis merekrut karyawan sebagai penjaga kedai dan petugas pengirim/ delivery.

2. Petugas pengantar/ delivery, pada saat kesempatan mengantar produk petugas membawa brosur/ leaflet varian produk yang dimiliki mitra bisnis, sehingga pelanggan dapat mengetahui produk lain yang dimiliki mitra bisnis dan diharapkan pelanggan membeli produk tersebut dikemudian hari.

3. Dengan menggunakan aplikasi penjualan online yang ada di situs penjualan dan social media, terbukti mengurangi biaya tenaga pemasaran, memperluas pasar sasaran dan jaringan pasar.

4. Dengan menggunakan aplikasi online dan situs penjualan online, terbukti meminimalisir biaya gaji tenaga pemasaran dan digantikan dengan biaya modal dengan menggunakan internet dan pulsa.

5. Setelah diberikan pelatihan tentang penggunaan aplikasi online (facebook, instagram, you tube), membuat akun, menggunakan aplikasi photo editor dan video editormakamitra bisnis dapat berkomunikasi secara online dengan pelanggan/ customer dan mendengarkan kebutuhan mereka secar realtime.

6. Disamping itu pula dari aplikasi penjualan online/ E-commerce mitra bisnis dapat melihat di kolom komentar pelanggan mitra bisnis, sehingga hal-hal yang baik tentang produk dari mitra bisnis dapat dipertahankan / mungkin ditingkatkan sedangkan hal-hal yang kurang disukai oleh pelanggan segera dapat dicarikan perbaikannya.

Kegiatan pengabdian dapat membuka wawasan masyarakat dengan 


\section{JURNAL ABDIMAS

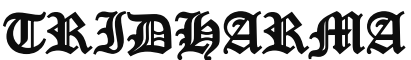

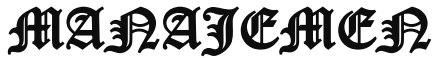

P-ISSN 2615-6849, E-ISSN 2716-070X

Jurnal ABDIMAS Vol. 1,No.2, Mei 2020,Hal(99-109)

@Prodi Manajemen Fakultas Ekonomi Universitas Pamulang

Email: abdimasjurnal.unpam@gmail.com Telp: (021) 741-2566 bertambahnya keilmuan bagi para anggota UKMP kota depok dalam pemilihan strategi yang tepat dalam penggunaan web ecommerce guna peningkatan pendapatan dan penerimaan produk dimasyarakat. Pelatihan dan penyuluhan yang diberikan kepada mitra bisnis bukan hanya seputar membuat akun penjualan online tetapi juga mitra bisnis diajarkan bagaimana cara mempost/ meng upload photo atau video produk mitra bisnis. Hal ini membuat pelanggan dan konsumen dapat terhubung secara realtime dimana mitra bisnis dapat bertemu dan mendengarkan kebutuhan pelanggan. Dengan pemasaran online mitra bisnis dapat meng update produk, info promosi produk, mendapatkan online review dari pelanggan terkait baik dan tidaknya produk yang dipasarkan serta review atau testimonial para pelanggan dapat mempengaruhi keputusan berbelanja dari pelanggan yang lainnya yang mungkin belum pernah mencoba atau membeli produk mitra bisnis dan meningkatkan pemberdayaan mitra.

\section{KESIMPULAN DAN SARAN}

\section{Kesimpulan}

Kegiatan pelaksanaan Pengabdian Kepada Masyarakat (PKM) di Balai Pertemuan Desa Sukmajaya Kelurahan Rangkapan Jaya Kecamatan Pancoran Mas, Kota Depok pada tanggal 4 - 6 Oktober 2019. Menghasilkan kesimpulan bahwa pemasaran menggunakan web ecommerce terbukti dapat meningkatkan pengembangan produk mitra bisnis baik dari sisi pendapatan / omset maupun dari sisi biaya.

Kegiatan PKM ini telah memberikan kontribusi kepada pelaku bisnis/mitra bisnis dengan memberikan solusi berupa pelatihan guna meningkatkan pengetahuan dalam penggunaan sosial media sebagai infrastruktur pemasaran produknya.
Berdasarkan kegiatan yang sudah terlaksana beberapa saran yang dapat kami sampaikan kedepan adalah diharapkan para pelaku bisnis/ mitra bisnis dapat konsisten melakukan inovasi produk dan pemasaran sehingga dapat mempengaruhi keputusan berbelanja pelanggan. Diharapkan mitra bisnis dapat mengembangkan bisnis tidak hanya di satu gerai/ kedai saja namun juga didaerah atau tempat lain sehingga pangsa pasarnya berkembang.

\section{DAFTAR PUSTAKA}

Barkatullah, Abdul Halim. Bisnis ECommerce, Yogyakarta: Pustaka Pelajar, 2006

Indrajit, Richardus Eko. E-Commerce:Kiat dan Strategi Bisnis Di Dunia Maya, Jakarta: PT. Elex Media Komputindo, 2001

Kotler dan Keller. 2009. Manajemen Pemasaran. Jilid I. Edisi ke 13. Jakarta: Erlangga

M.S, Jay. Peran E-Commerce dalam Sektor Ekonomi dan Industri, Jakarta: PT. Elex Media Komputindo, 2001

Oentoro, Deliyanti. 2010. Manajemen

$\begin{array}{lr}\text { Pemasaran } & \text { Modern. } \\ \text { Yogyakarta: } & \text { Laksbang } \\ \text { Pressindo. } & \end{array}$

Peter, J. Paul dan Jerry C. Olson. 2000. Consumer Behavior. Perilaku konsumen dan Strategi Pemasaran. Jilid 2.Edisi 4. Jakarta: Erlangga.

Tim LPPM Pamulang. 2016. Buku Panduan Penelitian dan Pengabdian Kepada Masyarakat. Universitas Pamulang. Tangerang Selatan

Tjiptono, Fandy. 2008. Strategi Pemasaran, Edisi Ketiga. Andi, Yogyakarta

W. Prurbo Onno dan Aang Arif Wahyudi. Mengenal E-Commerce, Jakarta: Elex Media Komputindo, 2001

\section{Saran}




\section{JURNAL ABDIMAS

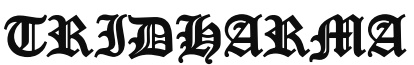 AlA:}

P-ISSN 2615-6849, E-ISSN 2716-070X

Jurnal ABDIMAS Vol. 1,No.2, Mei 2020,Hal(99-109)

@ Prodi Manajemen Fakultas Ekonomi Universitas Pamulang

Email: abdimasjurnal.unpam @ gmail.com Telp: (021) 741-2566

DOKUMENTASIFOTO KEGIATAN
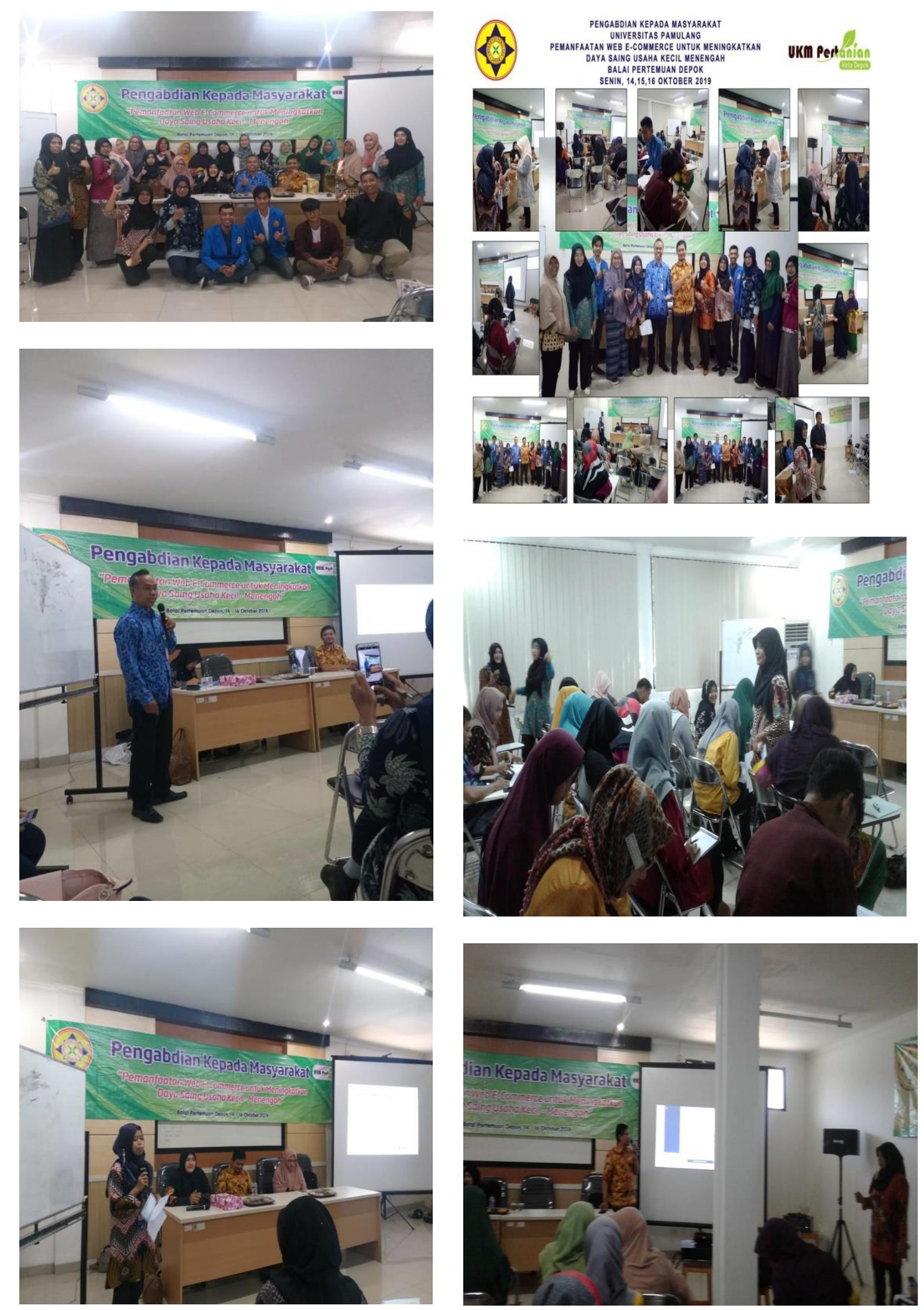